\title{
Designing and Evaluation of Skin Extract Agar for Isolation of Microflora from Raw Buffalo Hide
}

\author{
Ashish Polkade ${ }^{1}{ }^{2 \star}$, Prafulla Shede ${ }^{2,3},{\text { Pradhnya } \text { Kanekar }^{2} \text {, Prashant Dhakephalkar }}^{2}$, Seema Sarnaik ${ }^{2}$ \\ ${ }^{1}$ Microbial Culture Collection, National Centre For Cell Science, Ganeshkhind, Pune 411007 Maharashtra \\ ${ }^{2}$ Microbial Sciences Division, Agharkar Research Institute, Pune-411004 INDIA \\ ${ }^{3}$ Department of Microbiology Garware Collage, Pune, India
}

\begin{abstract}
Present study was aimed to design nutrient medium most suitable for isolation and enumeration of microbial flora associated with raw buffalo hide. Skin extract agar (SEA) was designed and standardized on the basis of its chemical analysis. SEA and nutrient medium supplemented with skin extract was inoculated with buffalo hide wash. Total viable count as well as diversity of microbial colonies were enumerated on SEA as well as on nutrient agar and standard plate count agar both supplemented with skin extract $(1 \% \mathrm{v} / \mathrm{v})$. Bacterial strains forming diverse types of colonies on the media tested were identified on the basis of their 16S rRNA gene sequences. The SEA was found to yield higher number of bacteria and to support growth of Acinetobacter, Exiguobacterium and Stenotrophomonas which otherwise difficult to selectively isolate from buffalo hide using nutrient agar and standard plate count agar. Diversity of microbial colonies formed on SEA was significantly higher than that observed on nutrient agar or standard plate count agar. Feasibility of utilizing SEA as a microbiological medium for isolation and identification of microflora from raw buffalo hide was successfully demonstrated. Use of skin extract medium can maximize recovery of taxonomically distinct bacteria from raw buffalo hide. This basic study, with proper manipulations could lead to development of product for enumeration and isolation of bacteria from buffalo hides especially cattle pathogens related to skin diseases.
\end{abstract}

Keywords: Skin extract; Microbiological media; Hide microflora; Raw buffalo hide
Received on: 12 Dec. 2012

Accepted on: 24 Jan. 2013

Published on: 13 Jan. 2014

DOI: $10.5195 /$ iioablett.2013.20

\section{INTRODUCTION}

Selection of nutrient media plays a key role in accessing this microbial diversity through culture based approach. Although, the culture medium design is ideally based on a sound understanding of microbial metabolism and physiology, composition of various media components is not always clear, especially in case of undefined medium. In past, specialized microbiological media were prepared using cattle whole blood as a protein substrate for cultivation of infectious bacteria from clinical samples (Zhubrenko et al., 1993). Fish waste i.e. Shrimp head and hulls were used for preparation of microbiological media by (Stephens et al., 1976). Sangali and Brandelli (2000) used medium supplemented with feather meal as only source for nitrogen in order to isolate keratinolytic microorganisms. Conventionally Beef extract and beef are used to prepare infusion media for microbial examination of butter. However, Blood agar has been the choice for isolation and identification of fastidious organisms (Difco manual, 1984). Differential medium for the isolation of Cronobacter spp. was developed by Kim and Rhee (2011).
The goal of any culture medium is simply to provide an environment where the nutritional needs of the microbe are met and the microbe will multiply. This means providing a source of carbon, nitrogen and electrons, a means for the microbe to generate energy and finally any specific growth factors that the microbe may require (Wink, 1992). Since Buffalo hide consists of high amount of protein $(33 \%)$, fat $(2 \%)$, mineral $(0.5 \%)$ and other including pigment (0.5\%) (Sharphouse, 1983), it can be a rich source of nitrogen (amino acids), carbon, energy, as well as many macro- and micronutrients.

Outermost covering of an animal (Hide) harbors diverse microbes affecting leather quality (Shede et al., 2008) as well as transfer to carcasses involving health problems in humans (Bell, 1997). Raw hide which is a protein rich outer flayed covering of large animals is used mainly for the manufacture of leather. After flaying, the hide must be preserved, so that its leather potential is retained or protected against the action of microorganisms. Microorganisms, especially bacteria present on the hide play an important role in causing deterioration of the hide when preserved at ambient temperature (Sharphouse, 1983). In order to know the bacterial 
diversity of the hide, studies were undertaken to isolate and identify bacteria present on the hide (Birbir and Baily, 2000, Birbir and Ilgaz, 1996). Studies on microflora of raw hide have been carried out with two major concerns i.e. effect on leather quality (Woods et al., 1971, Woods et al., 1972) and effect of microflora of hide on carcass contamination. Recently interest has been also developed due to environmental concerns in leather industries (Shede et al., 2009).

Selection of media for this study was most crucial in order to account for most of the bacterial flora residing on raw buffalo hide, both in qualitative and quantitative manner. It was believed that use of skin extract as a growth medium would provide microorganisms a nutritional environment that is similar to the one provided by raw buffalo hide. The main aim of the present investigation was to evaluate whether skin extract as a growth medium or its supplementation to standard nutrient medium could enhance isolation and enumeration of microorganisms from raw hide.

\section{MATERIALS AND METHODS}

\section{Preperation of Skin Extract}

Fresh raw buffalo hide was collected from slaughter house and chopped in to small pieces. These pieces were suspended in distilled water at concentration of 5\%, 10\% and $25 \% \mathrm{w} / \mathrm{v}$. Skin extract was prepared by two methods i.e. autoclaving $\left(121^{\circ} \mathrm{C}\right.$ for $\left.20 \mathrm{~min}\right)$ and boiling $(20 \mathrm{~min})$ skin pieces. The extract was then filtered through muslin cloth to remove solid part and measured for yield. The experiment was run in duplicate and the values in the Table 1 are average of two.

\section{Chemical Analysis of Skin Extract}

Skin extracts were analyzed for their chemical composition viz. carbon, $\mathrm{pH}$ and protein content. $\mathrm{pH}$ of the skin extract was determined using $\mathrm{pH}$ meter. Protein content of skin extract medium along with other conventional media was determined by burette method (Clark, 1964). Carbon content in the medium was analyzed using total organic carbon analyzer (ANA TOC series II, SGE Australia). Sample was acidified with perchloric acid to $\mathrm{pH} 3.5$ in order to remove inorganic carbon from it. Titanium dioxide, used as a catalyst, in presence of ultraviolet rays reacts with organic carbon and release carbon dioxide which is then detected by Non Dispersive Infrared (NDIR) Detector. Results were analyzed using reactive ${ }^{\mathrm{TM}}$ software and expressed in $\mathrm{g} \%$ release. The analysis was carried out in duplicate and the average values are detailed in Table 2 .

\section{Microbiological Evaluation of Skin Extract}

Skin extract was evaluated for its suitability in supporting growth of microorganisms from raw buffalo hide. Skin extract was compared with two commercially available media i.e. Nutrient agar (NA) and Standard Plate count agar (SPC). Effect of supplementation of skin extract with these media was also studied.

Nutrient broth contains Peptone $(0.5 \%)$ and beef extract $(0.3 \%)$ which contributes to total protein available for growth of microbes. Hence skin extract was diluted and incorporated in the medium at 1\% concentration of protein in NA and SPC. For preparation of skin extract agar (SEA), the extract was diluted to have $1 \%$ concentration of protein, $\mathrm{pH}$ was checked and adjusted to 7.0 and solidified with $1.8 \%$ agar powder.

\section{Sampling for Bacterial Isolation}

Raw buffalo hide was collected from Pune Municipal Corporation slaughter house immediately after flaying the slaughtered animal and transported to the laboratory in ice bucket maintaining the temperature $\sim 2-4^{\circ} \mathrm{C}$. Hide was cut into pieces of $2.5 \times 2.5 \mathrm{~cm}$ size and individual hide piece was suspended in $100 \mathrm{ml}$ sterile saline and incubated on rotary shaker $(150 \mathrm{rpm})$ at ambient temperature for 3 hours. The suspension was 10 fold serially diluted and used for determination of Total viable count (TVC) using spread plate technique. Standard plate count (SPC) agar and Nutrient agar (NA) were used as standard media along with supplemented media and SEA. All the plates were incubated for $48 \mathrm{~h}$ at $37^{\circ} \mathrm{C}$ and the number of total viable bacteria was noted as number of colony forming units (cfu) per unit area of hide. In all total four hide samples viz. BSC, BSD, BSE and BSF from different buffalos were processed.

\section{Isolation and Identification of Bacteria}

Morphologically distinct colonies were isolated from respective medium. These Isolates were grouped on the basis of their morphological and biochemical characters. Identification of selected isolates was carried out by $16 \mathrm{~S}$ ribosomal RNA gene sequencing. DNA of the isolates was extracted and purified using standard phenolchloroform extraction procedures. 16S rRNA genes were amplified from the total extracted DNA by PCR using 
universal

primers

FDD2

(5'ccggatccgtcgacagagtttgatcitggctcag3') and RPP2 (5'ccaagcttctagacggitaccttgttacgactt3'). The PCR reaction mixture contained $0.2 \mathrm{M}$ each $\mathrm{dNTP}, 4$ pM each primer, 200ng template and 0.33U Taq DNA polymerase (Bangalore Genei, India) with a reaction buffer (1X) supplied by the manufacturer in a total volume of $20 \mu \mathrm{l}$. PCR was performed with an initial denaturation at $94^{\circ} \mathrm{C}$ for 5 minutes, thirty cycles of one minute at $94^{\circ} \mathrm{C}$, one minute at $62^{\circ} \mathrm{C}$ and one minute at $72^{\circ} \mathrm{C}$, followed by a final 20 minute extension at $72^{\circ} \mathrm{C}$. PCR products were purified by PEG-NaCl method. Approximately 100ng purified PCR product was used for sequencing PCR using Big Dye ${ }^{\circledR}$ Terminator sequencing kit from Applied Biosystems. Sequencing was carried out on 3100 AVANT automated sequencer (Applied Biosystems, USA).The $16 \mathrm{~S}$ rDNA sequences have been submitted to Genebank databases.

Table 1. Yield, $\mathrm{pH}$ and protein content of skin extract

\begin{tabular}{|c|c|c|c|c|c|c|}
\hline \multirow{2}{*}{$\begin{array}{l}\text { Concentration of skin piece in distilled water } \\
\qquad(w / v)\end{array}$} & \multicolumn{2}{|c|}{ Yield (\%) } & \multicolumn{2}{|c|}{ pH } & \multicolumn{2}{|c|}{ Protein content ( $\%$ ) } \\
\hline & Boiled & Autoclaved & Boiled & Autoclaved & Boiled & Autoclaved \\
\hline $5 \%$ & 70 & 73 & 8.3 & 6.5 & 0.138 & 0.617 \\
\hline $10 \%$ & 63 & 73 & 6.7 & 6.5 & 0.192 & 1.544 \\
\hline $25 \%$ & 50 & 52 & 6.8 & 6.5 & 0.376 & 1.931 \\
\hline
\end{tabular}

Table 2: Chemical analysis of media

\begin{tabular}{lcc}
\hline Media & pH of media after autoclaving & Protein (g \%) \\
\hline Skin extract $5 \%$ & 6.5 & 0.617 \\
Skin extract $10 \%$ & 6.5 & 1.544 \\
Skin Extract $25 \%$ & 6.5 & 1.931 \\
Nutrient Broth & 7.6 & 0.3368 \\
Standard plate count broth & 6.3 & 13.53 \\
\hline
\end{tabular}

\section{RESULTS AND DISCUSSIONS}

\section{Skin Extract Standardization}

During standardization of protocol for skin extract preparation, two methods along with three different concentrations of skin pieces $(\mathrm{w} / \mathrm{v})$ were tested. Yield of extract obtained after filtration and protein content was higher and $\mathrm{pH}$ was constant in case of extract prepared by autoclaving (Table 1 ).

It was observed that autoclaving of skin released more amount of protein as compared to boiling. Skin extract with $25 \%$ skin released highest possible protein from skin compared to lower concentrations. Hence method to autoclave skin pieces at $25 \% \mathrm{w} / \mathrm{v}$ concentration was used to prepare SEA for further studies.

\section{Chemical Analysis of Media}

Values for $\mathrm{pH}$ of standard media varied from 6.3 to 7.5. It was found that values for SEA along with supplemented media lies in the same range. Cattle blood hydrolysate shows presence of $14 \%$ total protein which was used for isolation of infectious bacteria (Zhurbenko et al., 1993), whereas values obtained in case of skin extract at $25 \% \mathrm{w} / \mathrm{v}$ concentration shows $16 \%$ of protein. Protein content even at $5 \% \mathrm{w} / \mathrm{v}$ skin extract showed higher protein content than that of standard media. Skin extract $(25 \%)$ without agar showed TOC comparable with that of Nutrient broth and SPC broth (Table 2).

\section{Skin Extract for Microbial Growth}


Enumeration of bacterial flora associated with buffalo hide using skin extract agar as well as NA and SPC revealed that the TVC obtained on SEA was comparable with commercially available media. In case of sample BSC there was increase in TVC on skin extract agar as compared to NA and SPC. Although TVC differs on different media in respective sample, the difference is not more than 10 fold (Figure 1).These variations may depend on type of bacteria present on hide since their nutritional requirement plays an important role in utilizing specific medium for their growth.

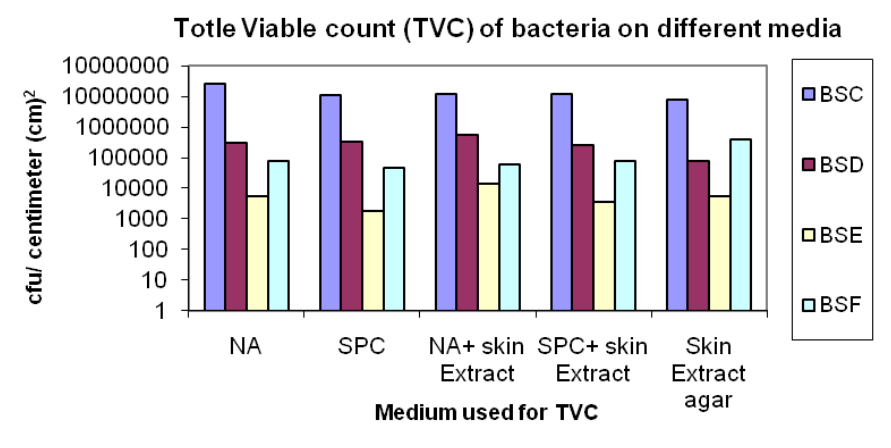

Figure 1. Total viable count of bacteria from different animal samples (BSC, BSD, BSE, and BSF) on different media (SEA- Skin Extract Agar; NA- Nutrient Agar; SPC- Standard Plate Count Agar; SE- Skin extract)

In all 65 isolates showing distinct morphological characters were isolated from two skin samples using different media (Table 3). The identification of isolates along with their respective Gene bank accession numbers are described in Table 4.

Identification of bacterial isolates revealed presence of in all eight genera on raw buffalo hide .Standard media showed presence of three genera, supplemented media showed four genera while SEA supported growth of six genera.

It was interesting to note that higher number of organisms could be obtained using skin extract agar than that of standard media used for isolation. During qualitative study of micro flora, isolates from skin extract agar showed higher degree of diversity as compared to Nutrient agar and SPC.Thus skin extract would favor growth of some bacterial genera like Acinetobacter, Escherichia and Stenotrophomonas different from those growing on NA or SPC. Exiguobacterim and Micrococcus are also different genera isolated from media supplemented with skin extract than standard media used alone.

Table 3: Morphologically distinct isolates from different media

\begin{tabular}{|ccccc}
\hline \multicolumn{5}{|c}{ Media and Number of Morphologically distinct colonies } \\
\hline SEA & NA & NA + SE & SPC & SPC + SE \\
\hline 24 & 14 & 10 & 6 & 11 \\
\hline
\end{tabular}

SEA- Skin Extract Agar; NA- Nutrient Agar; SPC- Standard Plate Count Agar; SE- Skin extract

\begin{tabular}{|c|c|c|c|c|}
\hline $\begin{array}{l}\text { Bacterial genus } \\
\text { identified }\end{array}$ & $\begin{array}{l}\text { NA } \\
\text { and } \\
\text { SPC }\end{array}$ & $\begin{array}{c}\text { NA and SPC } \\
\text { with SEA } \\
\text { supplement }\end{array}$ & SEA & $\begin{array}{l}\text { Gene bank accession } \\
\text { numbers }\end{array}$ \\
\hline Staphylococcus & + & + & + & $\begin{array}{l}\text { DQ536508,DQ536509 } \\
\text { DQ518614 }\end{array}$ \\
\hline Pseudomonas & + & - & + & DQ518597, DQ518613 \\
\hline Shigella & + & - & + & DQ518598, DQ518591 \\
\hline Acinetobacter & - & - & + & DQ518593 \\
\hline Stenotrophomonas & - & - & + & DQ518596 \\
\hline Exiguobacterium & - & + & - & DQ789992 \\
\hline Escherichia & - & + & + & DQ518594 DQ517912 \\
\hline Macrococcus & - & + & - & DQ518592 \\
\hline
\end{tabular}

NA- Nutrient Agar; SPC- Standard Plate Count Agar; SEA- Skin Extract Agar

The skin Extract may contain some unidentified components which favor growth of some bacterial genera on the same medium. Although the genera obtained using skin extract agar can grow on standard media when grown singly, but our results indicate that skin extract allows growth of maximum number of diverse bacterial genera from a given sample. Use of Skin extract and its supplementation minimizes the chances of elimination of some bacterial genera (Acinetobacter, Exiguobacterium and Stenotrophomonas) from total diversity.

Ali et al., (2012) showed through their research that the efficiency of isolation of microbes (Pathogens from Onion) can be increased with the use of components from its ecological niche (Onion). Although Luria broth can support the growth of onion pathogens but Onion extract medium (OEM) gives higher plating efficiency. Similar way results obtained in the present study supports that skin extract could definitely help in maximizing recovery of taxonomically distinct bacteria from raw buffalo hide. The SEA would also be a cheap 
nutrient medium as compared to NA or SPC agar (Rs.7.148 / 100ml SPC Agar, Rs.7.09 for 100ml NA and Rs.2.13 for $100 \mathrm{ml}$ Skin Extract Agar).

Number of researchers have reported that media prepared from components of ecological niche could be of great importance for isolations as it provides a necessary growth factors e.g. cattle blood for infectious organisms (Zhurbenko et al.1993), fish peptone for fish pathogens (Subbannayya and Udayalaxmi, 2005) addition of salt to isolate microbes from brine solution (Kallenberger 1984). Recently Ali et al. (2012) also reported the semi-selective medium called as Onion Extract Medium (OEM) for rapid isolation of pathogenic strains related to onion. Thus present study also confirms the ability of skin extract to isolate bacteria associated with skin and probable pathogenic strains from the skin. Thus, it is possible to use skin extract agar as a complete medium or enrichment component for isolation and study of cattle pathogens particularly related to skin diseases. With proper manipulations in the process it could also possible to increase nutrient recovery from skin and product can be developed to high grade product for microbiological study.

\section{CONCLUSION}

We have demonstrated the feasibility of utilizing skin extract as a microbiological medium for the enumeration and isolation of bacteria from raw buffalo hide.

\section{ACKNOWLEDGEMENTS}

We thank Council for Scientific and Industrial Research (CSIR), Govt. of India for financial support to carry out the work.

\section{REFERENCES}

Ali MZ, Jean MB, Steven VB (2012) OEM-A new medium for rapid isolation of onion-pathogenic and onion-associated bacteria. Journal of Microbiological Methods 91: 520-526.

Bell RG (1997) Distribution and sources of microbial contamination on beef carcasses Journal of Applied Microbiology 82: 292-300.

Birbir M, Ilgaz A (1996) Isolation and identification of bacteria adversely affecting hide and leather quality. Journal of the Society of Leather Technologist and Chemists 80: 147-153.
Birbir M, Bailey DG (2000) Controlling the growth of extremely halophilic bacteria on brine cured cattle hides. Journal for Society of Leather Technologist and Chemist 84: 201-204.

Clark JM, Jr. ed. (1964) Experimental biochemistry, Freeman WH and Company, San Francisco.

Cyzeska FJ, Seiter JA, Marks SN, Jay JM (1981) Culture medium for selective isolation and enumeration of gram-negative bacteria from ground meats. Applied and Environmental Microbiology 42: 303-307.

Difco Manual (1984) Dehydrated culture media and reagents for microbiology, Detroit Michigan (USA) ISBN 0-9613169-9-3.

Kallenberger WE (1984) Halophilic bacteria in brine curing. Journal of the American Leather Chemists Association 79: 104-114.

Kim SA, Rhee MS, (2011) A new cost-effective, selective and differential medium for isolation of Cronobacter spp. Journal of Microbiological Methods 85: 149-154.

Sangali, S, Brandelli A, (2000) Feather keratin hydrolysis by a Vibrio sp. strain kr2. Journal of Applied Microbiology 89: 735-743.

Sharphouse JH, (1983) Leather technician's handbook. 2nd ed., Pub. Leather Producers Association, London.

Shede PN, Kanekar PP, Polkade AV, Sarnaik SS, Dhakephalkar PK (2008) Bacterial succession on raw buffalo hide and their degradative activities during ambient storage. International Biodeterioration and Biodegradation 62: 65-74.

Shede PN, Kanekar PP, Polkade AV, Sarnaik SS, Dhakephalkar PK, Chiplonkar SA, Nilegaonkar SS (2009) Effect of microbial activities on stored raw buffalo hide. Journal of Environmental Biology 30 (6): 983988.

Stephens NL, Bough WA, Beuchat LR, Heaton EK (1976) Preparation and evaluation of two microbiological media from shrimp heads and hulls. Journal of Applied Microbiology 31: 1-6.

Subbannayya K, Udayalaxmi S (2005) Fishmeal extract agar a medium to inhibit swarming of proteus species. Current Science 89 (10):16661667.

Wink GH (1992) Microbiological assessment of culture media: comparison and statistical evaluation of methods. International Journal of Food Microbiology 17: (2)159-81. 
Woods DR, Welton R L, Cooper DR (1971) The microbiology of curing and tanning processes. Part V. Anaerobic studies on halophobic and halophilic bacteria from cured hides. Journal of the American Leather Chemists Association 66: 496-503.

Woods DR, Welton RL, Thomson JA (1972) The microbiology of curing and tanning process. Journal of the American Leather Chemists Association 68: 217-225.

Zhurbenko RS, Barroetabenia MF, Rodriguez MC, Varela Yanez AF (1993) The possibility of using a bacteriological peptone from whole blood as the nutrient base for growing microorganisms. Journal of Microbiology Epidemiology and Immunobiology 2: 23-27.

\section{AUTHORS}

\section{Ashish Polkade, PhD}

$\mathrm{He}$ is working as aScientist at Microbial Culture Collection, National Centre for Cell Science, Pune, M.S., India. His major research interest are culture based microbial diversity studies, environmental microbiology etc.

\section{Prafulla Shede, $\mathrm{PhD}$}

$\mathrm{He}$ is working as an Assistant Professor at Department of Microbiology,
Abasaheb Garware College, Pune, M.S., India. His major research interests are renewable energy, biodegradation and bioremedaition of xenobiotics, bioreactor designing and fermentation technologies.

\section{Pradhnya Kanekar, PhD}

She is working as an Emirates Scientist at Microbial Sciences Division of MACSAgharkar Research Institute, Pune, M.S., India. Her main areas of interest are Biodegradation and bioremediation of toxic organic pollutants, Microbial diversity and conservation of bacteria and archae, and Biotechnological potential of extremophiles.

\section{Prashant Dhakephalkar, PhD}

He has been working as a Scientist at Microbial Sciences Division of MACSAgharkar Research Institute, Pune, M.S. India. His major research interests are microbial diversity of extreme and pristine environment, plasmid curing agents of herbal origin, environmental \& microbial technology etc.

\section{Seema Sarnaik, PhD}

She is working as a Senior Scientist at Microbial Sciences Division of MACSAgharkar Research Institute, Pune, M.S. India. Her major research interests includes Microbial treatment of industrial effluent and Production of industrially important enzymes.

\section{ULIS D-Sorke}

This journal is published by the University Library System of the University of Pittsburgh

as part of its D-Scribe Digital Publishing Program, and is cosponsored by the University of Pittsburgh Press. 